\title{
An Acto-Myosin II Constricting Ring Initiates the Fission of Activity-Dependent Bulk Endosomes in Neurosecretory Cells
}

\author{
Rachel S. Gormal, ${ }^{\star}$ Tam H. Nguyen, ${ }^{*}$ Sally Martin, Andreas Papadopulos, and Frederic A. Meunier \\ The Clem Jones Centre for Ageing Dementia Research, Queensland Brain Institute, University of Queensland, Brisbane 4072, Queensland, Australia
}

Activity-dependent bulk endocytosis allows neurons to internalize large portions of the plasma membrane in response to stimulation. However, whether this critical type of compensatory endocytosis is unique to neurons or also occurs in other excitable cells is currently unknown. Here we used fluorescent $70 \mathrm{kDa}$ dextran to demonstrate that secretagogue-induced bulk endocytosis also occurs in bovine chromaffin cells. The relatively large size of the bulk endosomes found in this model allowed us to investigate how the neck of the budding endosomes constricts to allow efficient recruitment of the fission machinery. Using time-lapse imaging of Lifeact-GFP-transfected chromaffin cells in combination with fluorescent $70 \mathrm{kDa}$ dextran, we detected acto-myosin II rings surrounding dextran-positive budding endosomes. Importantly, these rings were transient and contracted before disappearing, suggesting that they might be involved in restricting the size of the budding endosome neck. Based on the complete recovery of dextran fluorescence after photobleaching, we demonstrated that the actin ring-associated budding endosomes were still connected with the extracellular fluid. In contrast, no such recovery was observed following the constriction and disappearance of the actin rings, suggesting that these structures were pinched-off endosomes. Finally, we showed that the rings were initiated by a circular array of phosphatidylinositol(4,5)bisphosphate microdomains, and that their constriction was sensitive to both myosin II and dynamin inhibition. The acto-myosin II rings therefore play a key role in constricting the neck of budding bulk endosomes before dynamin-dependent fission from the plasma membrane of neurosecretory cells.

Key words: actin; cytoskeleton; dynamin; endocytosis; myosin II; PIP2

\section{Introduction}

Activity-dependent bulk endocytosis (ADBE) involves the retrieval of large amounts of plasma membrane in response to sustained stimulation, thereby generating bulk endosomes that can take up a significant volume of nerve terminals (Miller and Heuser, 1984; Richards et al., 2000; Clayton et al., 2008). Contrary to the well defined molecular understanding of clathrin-mediated endocytosis (CME), little is known about the mechanism underpinning ADBE. Whether this important mode of endocytosis is limited to neurons or can also occur in other innervated cell types such as neurosecretory cells remains unclear. Furthermore, the mechanism leading the neck of such large plasma membrane invaginations to constrict to a size that allows the fission machinery to be recruited and become active is currently unknown. Most

\footnotetext{
Received Aug. 5, 2014; revised Nov. 19, 2014; accepted Nov. 26, 2014.

Author contributions: R.S.G., T.H.N., and F.A.M. designed research; R.S.G., T.H.N., S.M., and A.P. performed research; R.S.G., T.H.N., and S.M. analyzed data; R.S.G., T.H.N., and F.A.M. wrote the paper.

This work was supported by Project Grant DP120104057 from the Australia Research Council (to F.A.M.) and Australian Research Council LIEF Grant LE130100078. F.A.M. is a National Health and Medical Research Council Senior Research Fellow (APP569596). We thank Phil Robinson (Children's Medical Research Institute, Sydney, New South Wales, Autstralia), Alpha Yap, and Annette Shewan (University of Queensland, Brisbane, Queensland, Australia) for the gift of plasmids and dynamin inhibitor, and for insightful discussions. We also thank Luke Hammond for technical support with microscopy experiments, Rowan Tweedale for corrections to this manuscript, and Tomas Kirchhausen for invaluable comments.

*R.S.G. and T.H.N. contributed equally to this work.

Correspondence should be addressed to Frederic A. Meunier, The Clem Jones Centre for Ageing Dementia Research, Queensland Brain Institute, The University of Queensland, Brisbane 4072, Queensland, Australia. E-mail: f.meunier@uq.edu.au.

DOI:10.1523/JNEUROSCI.3228-14.2015

Copyright $\odot 2015$ the authors $\quad 0270-6474 / 15 / 351380-10 \$ 15.00 / 0$
}

studies have investigated ADBE in neurons, the relatively small size of the nerve terminals is a major hindrance to further defining the underpinning mechanism. Although chromaffin cells have been shown to undergo compensatory endocytosis (Perrais et al., 2004; Ceridono et al., 2011), whether they also undergo $\mathrm{ADBE}$ is currently unknown. Here, we demonstrate that bovine adrenal chromaffin cells also undergo bulk endocytosis in response to secretagogue stimulation. Importantly, we discovered that budding bulk endosomes are surrounded by an acto-myosin II ring, the contraction of which is key to promoting fission from the plasma membrane. Moreover, phosphatidylinositol $(4,5)$ bisphosphate $\left[\operatorname{PtdIns}(4,5) \mathrm{P}_{2}\right]$, dynamin, and myosin II also contribute to initiating the bulk invagination before fission. Our results provide the first demonstration that $\mathrm{ADBE}$ is not limited to neurons but also occurs in neurosecretory cells. We further reveal how, in these cells, actomyosin II constricting rings directly constrict the neck of nascent bulk endosome before dynamin-mediated fission.

\section{Materials and Methods}

Chromaffin cell preparation and transfection. Chromaffin cells were isolated from protease digestion of bovine adrenal glands (derived from either sex), as described previously (Meunier et al., 2002, 2005) and maintained in DMEM supplemented with $10 \%$ serum supreme, 2.5 $\mu \mathrm{g} / \mathrm{ml}$ fungizone, $50 \mu \mathrm{g} / \mathrm{ml}$ gentamycin, and $10 \mathrm{~mm}$ HEPES on poly-Dlysine-coated culture dishes (MatTek Corporation). Cells were transfected by electroporation using Amaxa Rat Neuron Nucleofector Kits (Lonza), plated onto glass-bottom dishes (MatTek Corporation), and cultured at $37^{\circ} \mathrm{C} / 5 \% \mathrm{CO}_{2}$ for $24-72 \mathrm{~h}$ before experimentation. Lifeact-GFP and Lifeact-RFP (Riedl et al., 2008) were provided by Roland Wedlich Soldner (University of Münster, Germany), glycosyl phosphatidyl 
A
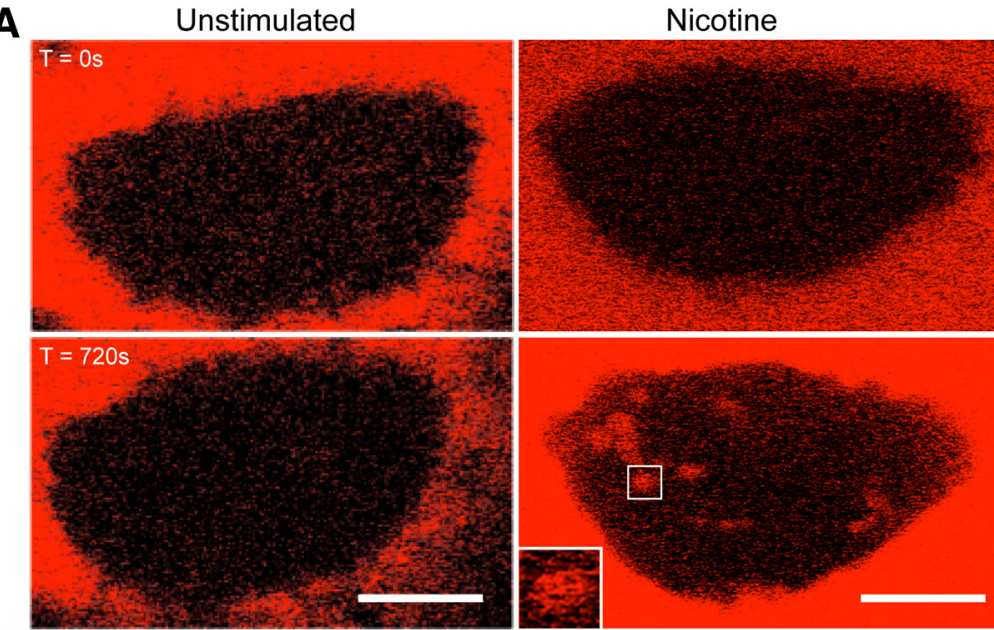

C
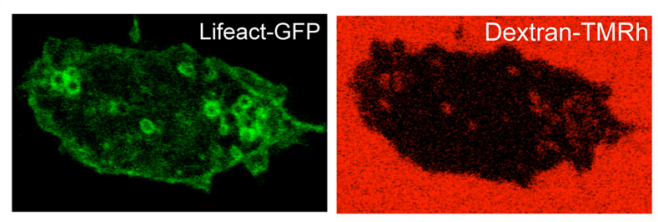

D
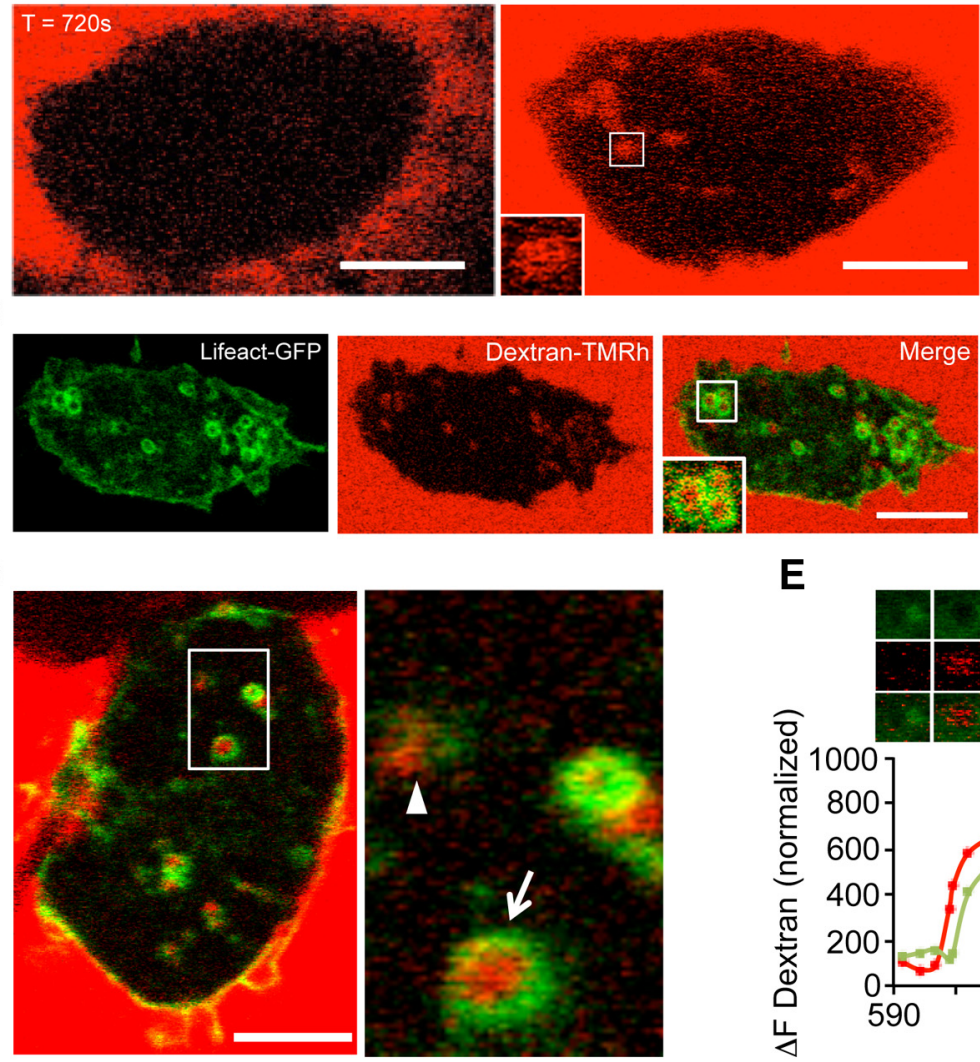

$\mathbf{F}$

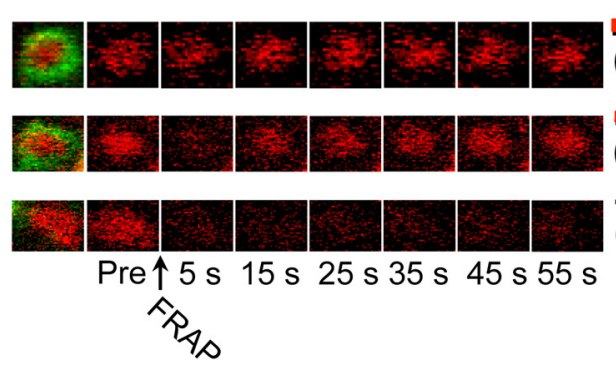

E

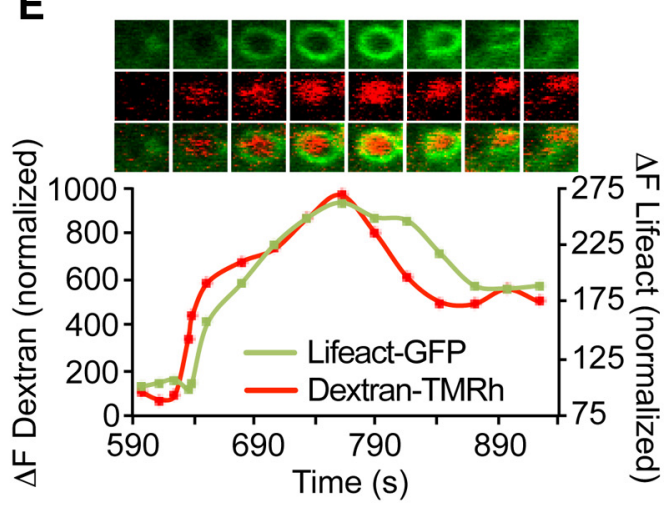

B
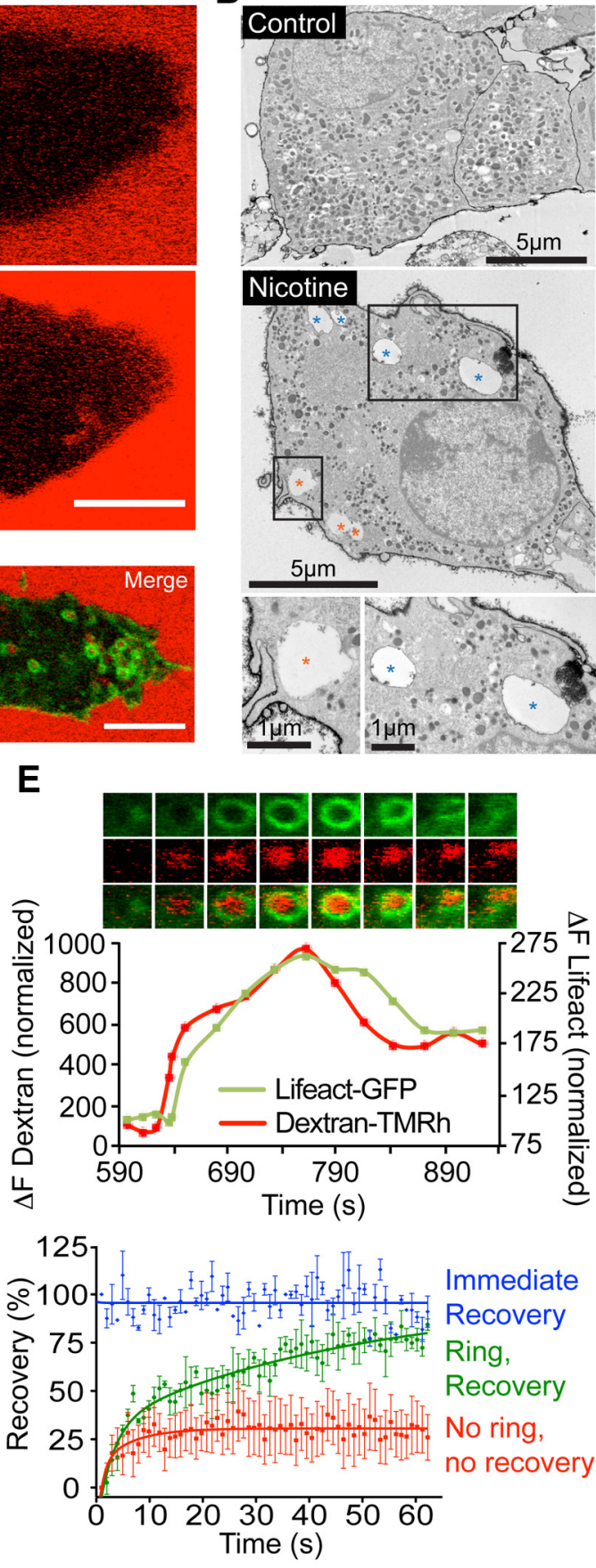

Figure 1. Evidence for activity-dependent bulk endocytosis in chromaffin cells. $A$, Bovine adrenal chromaffin cells were incubated with $70 \mathrm{kDa}$ dextran-Tetramethylrodamine (TMRh) in the presence or absence of nicotine $(100 \mu \mathrm{m})$ while being imaged by time-lapse confocal microscopy at the level of the footprint (surface area in contact with the coverslip). Internal dextran-positive structures appeared after stimulation. B, Bovine chromaffin cells were treated with vehicle (control) or nicotine (100 $\mu \mathrm{m})$ for $8 \mathrm{~min}$, and the cell surface stained with ruthenium red during fixation. Electron microscopy images show the appearance of largecell surface connected (red asterisk, electron densedeposits) and disconnected (blue asterisk) membrane-bound vacuoles in stimulated cells. C, Lifeact-GFP transfected chromaffin cells were stimulated with nicotine (100 $\mu \mathrm{M})$ in the presence of $70 \mathrm{kDa}$ dextran-TMRh and imaged after 15 min of stimulation. Note that some of the intemal dextran-positive structures are surrounded by one actin (Lifeact-positive) ring. $\boldsymbol{D}$, Another example of a nicotine-stimulated chromaffin cell showing a dextran-positive structure not associated with an actin ring (arrowhead) and several others surrounded by an actin ring (arrow). E, Lifeact-GFP-transfected chromaffin cells were stimulated with nicotine $(100 \mu \mathrm{m})$ in the presence of $70 \mathrm{kDa}$ dextran-TMRh and time-lapse imaged $(0.5 \mathrm{~Hz})$. A region of interesthighlighting the appearance of an individual dextran-positive structure surrounded by an actin ring is illustrated. The panels match the timing on the normalized fluorescence intensity graph below. Note the appearance of the dextran-positive structure prior to the formation of the actin ring and the change in actin ring diameter. F, Dextran-positive structures were photobleached using 100\% laser (20 iterations) and time-lapseimaged at $0.5 \mathrm{~Hz}$ ( $n=3$ from three cells (Immediate Recovery), $n=3$ from 3 cells (Ring, Recovery), $n=6$ from 4cells(Noring, no recovery).Dextran surrounded byan actinning recoveredfully witharange of kineticsfromfast(top, bluetrace)togradual (middle, green trace). Dextran-positivestructuresnotassociated withactin ringsfailed to recover (bottom, red trace). The diagram is indicative of the dextran-refilling model proposed for each condition. Scale bars, $5 \mu$ m unless otherwise stated. Error bars are expressed as mean \pm SEM.

inositol (GPI)-anchored GFP (GFP-GPI) was a gift from Kai Simons (Max Planck Institute of Molecular Cell Biology and Genetics, Germany), and pleckstrin homology domain of phospholipase C $\delta$ (PH-PLC $\delta$-RFP) was a gift from Tamas Balla (NIH, Bethesda, MD) (Várnai et al., 2002).
Confocal microscopy. Transfected cells were visualized with a 510 Meta confocal inverted microscope (Zeiss). The laser power was set at $1 \%$ for the $488 \mathrm{~nm}$ argon laser and $<2 \%$ for the $561 \mathrm{~nm}$ laser, and a $63 \times$ oil objective (numerical aperture, 1.4) was used. Cells were washed with and 
bathed in Buffer A (145 mM NaCl, $5 \mathrm{~mm} \mathrm{KCl}$, $1.2 \mathrm{mM} \mathrm{Na}_{2} \mathrm{HPO}_{4}, 10 \mathrm{~mm}$ D-glucose, $20 \mathrm{~mm}$ HEPES-NaOH, 2 mm $\mathrm{CaCl}_{2}$, pH 7.4) before stimulation with either nicotine $(100 \mu \mathrm{M})$ or barium chloride $(2 \mathrm{~mm})$. For dextran uptake experiments, cells were bathed in Buffer A containing $70 \mathrm{kDa}$ dextran conjugated to either fluorescein or tetramethyl rhodamine ( $5 \mu \mathrm{M}$; Life Technologies). For experiments involving pharmacological treatment with inhibitors, cells were pretreated with blebbistatin $(10 \mu \mathrm{M})$, cytochalasin D $(10 \mu \mathrm{M})$, or Dyngo4a $(30 \mu \mathrm{M})$ for 10 and 30 min respectively, before stimulation with nicotine. Time-lapse images were acquired at 1 frame $/ 2 \mathrm{~s}$ over the $15-25 \mathrm{~min}$ stimulation period.

Structured illumination microscopy. Transfected chromaffin cells expressing Lifeact-GFP were imaged using structured illumination microscopy (SIM; ELYRA PS1, Zeiss) equipped with a $100 \times$ objective ( $\alpha$ Plan-Apochromat $100 \times / 1.46$ oil-immersion) and a PCO scientific CMOS camera. Images were obtained by acquiring $z$-stacks of 10 slices with a spacing of 0.101 $\mu \mathrm{m}$, an exposure time of $100 \mathrm{~ms}$, a SIM grating size of $42 \mu \mathrm{m}$, and using three rotations. 3D structured illumination images were then processed using Zen software.

Electron microscopy. Bovine chromaffin cells were incubated in growth medium $\pm 100 \mu \mathrm{M}$ nicotine for $8 \mathrm{~min}$ before fixation in 2.5\% glutaraldehyde in the presence or absence of $0.1 \%$ ruthenium red (Electron Microscopy Sciences). Fixed cells were contrasted with $1 \%$ osmium tetroxide $\pm 0.1 \%$ ruthenium red and $4 \%$ uranyl acetate before dehydration and embedding in LX-112 resin (Martin et al., 2013). Sections $(50 \mathrm{~nm})$ were cut using an ultramicrotome (model UC64; Leica) and imaged using a transmission electron microscope (model 1011; JEOL) equipped with a cooled chargecoupled device camera (Morada; Olympus). All images were processed using Photoshop CS5.1 (Adobe), and figures were compiled with Illustrator CS5.1 (Adobe).

Fluorescence recovery after photobleaching analysis. Fluorescence recovery after photobleaching (FRAP) experiments were performed by exposing defined regions of cells to $100 \%$ argon 488 or $561 \mathrm{~nm}$ laser intensity for 20 iterations. The fluorescence intensity was measured in the photobleached area and background using Zeiss ZEN software. The background was subtracted from each data point. Fluorescence recovery was determined by either normalization of values by ( 1 ) the percentage of initial fluorescence after photobleaching (Figs. $1 F, 2 B$ ) or (2) the percentage of fluorescence intensity before bleaching (see Figs. 5G, 6B). Mobile fractions were calculated using Zen software from regions of interest of photobleached GPI (Fig. 2C; see Fig. $5 H$ ).

Immunocytochemistry. Cells cultured on coverslips were fixed with $4 \%$ paraformaldehyde/PBS for $20 \mathrm{~min}$, quenched with $\mathrm{NHCl}_{4} / \mathrm{PBS}(50 \mathrm{~mm}$ ) for $10 \mathrm{~min}$, permeabilized in $0.1 \%$ Triton X100/PBS for $10 \mathrm{~min}$, and then blocked with blocking buffer ( $0.2 \%$ BSA $/ 0.2 \%$ fish skin gelatin in PBS) for $10 \mathrm{~min}$. Coverslips were incubated with primary antibodies for $2 \mathrm{~h}$ at room temperature or $4^{\circ} \mathrm{C}$ overnight and washed with PBS, followed by $1 \mathrm{~h}$ incubation with fluorescently labeled secondary antibodies (Life Technologies). For actin-labeling experiments, phalloidin-488 (13 nm; Life Technologies) was included during the secondary antibody step. Coverslips were
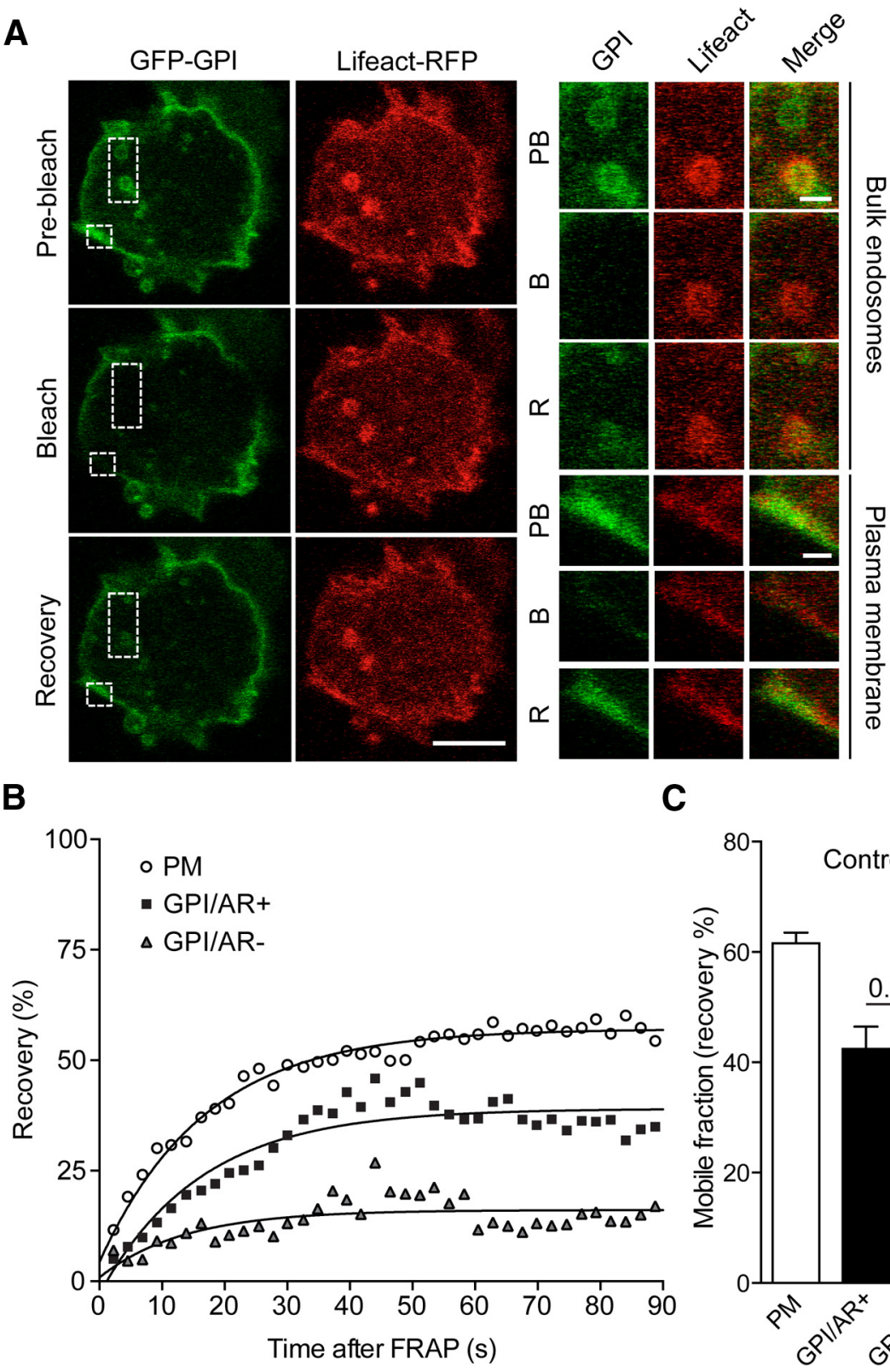

C

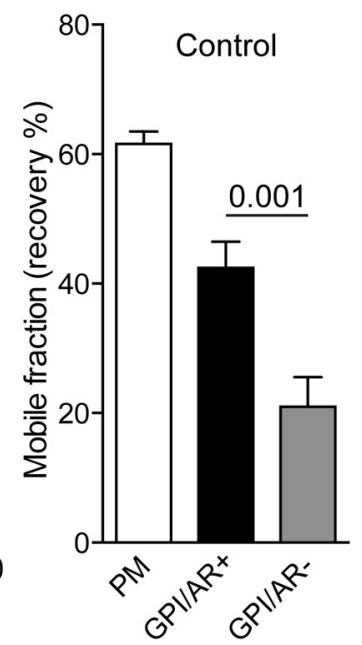

Figure 2. Actin rings colocalize with GFP-GPI, a plasma membrane probe. $\boldsymbol{A}$, Chromaffin cells cotransfected with GFP-GPI and Lifeact-RFP were stimulated with nicotine $(100 \mu \mathrm{m})$ and visualized by time-lapse confocal microscopy. GPI-positive internalized structures were subsequently subjected to FRAP (100\% argon laser, 20 iterations), and fluorescence recovery (mobile fraction) was analyzed. Scale bars: $\boldsymbol{A}, 10 \mu \mathrm{m}$, inset, $1 \mu \mathrm{m}$. $\boldsymbol{B}$, Plasma membrane area were used as a control for recovery. GPI-positive rings that were also positive for Lifeact-RFP actin ring (GPI/Actin Ring Positive: $A R+$ ) were shown to recover to a greater extent than GPI-positive rings with no Lifeact-RFP positive actin ring association (GPI/Actin Ring Negative: AR-). C, GPI-positive rings without actin ring association (GPI/AR -$)$ were unable to recover $(p<0.01 ; n=16$ cells). Error bars are mean \pm SEM.

mounted on glass slides with Prolong Gold (Life Technologies) for confocal imaging on a Zeiss 510 Meta confocal microscope. Myosin IIa and IIb primary antibodies were used as per the manufacturer's instruction (Sigma-Aldrich).

Statistical analysis. All experiments were repeated at least three times. Data analysis was performed using Student's $t$ test, and data were considered significant at $p<0.05$. Values are expressed as the mean \pm SEM.

\section{Results}

Evidence for activity-dependent bulk endocytosis in chromaffin cells

Due to its large size, high-molecular-weight dextran $(70 \mathrm{kDa})$ can be used as a marker for bulk endocytosis (Clayton and Cousin, 
A

B
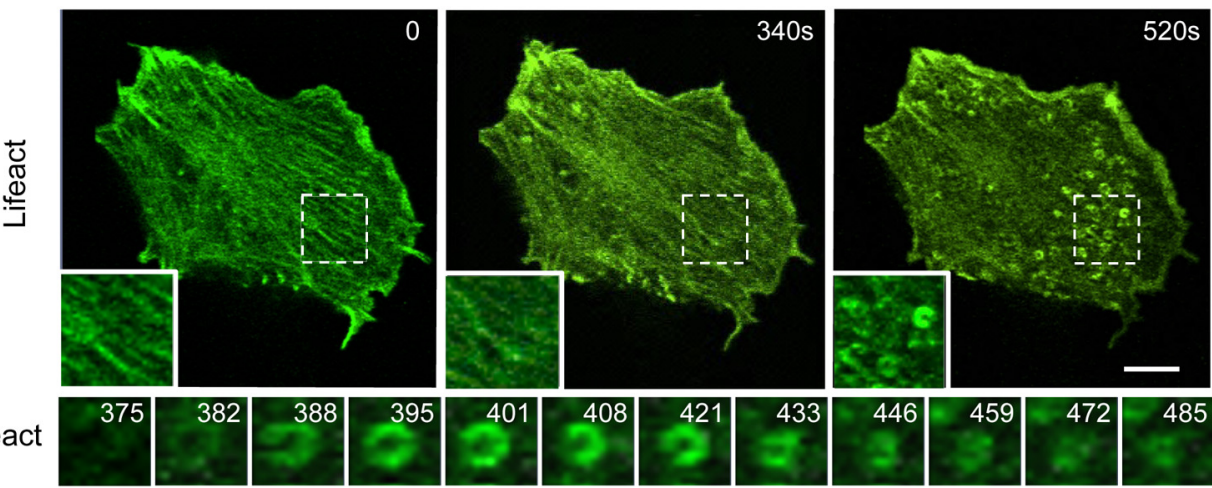

C

D

E
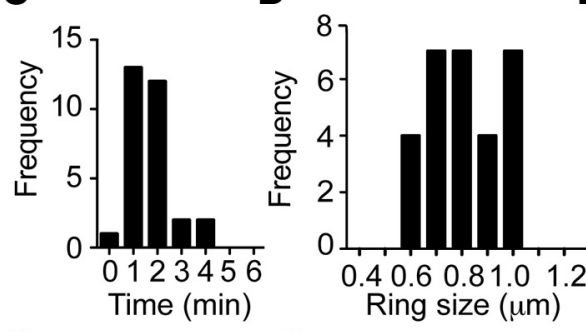

H Nicotine

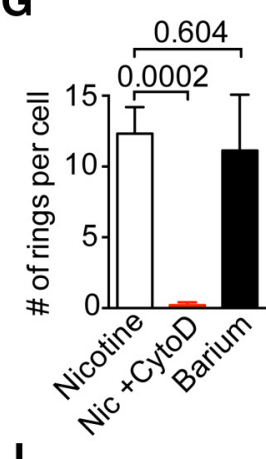

J

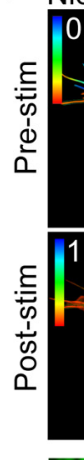

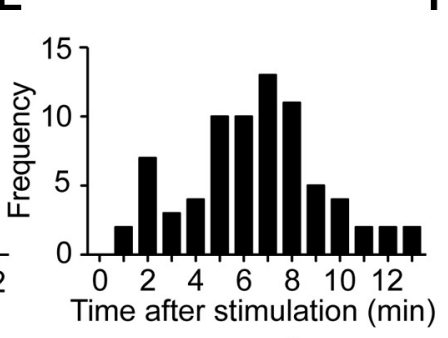

F Nicotine

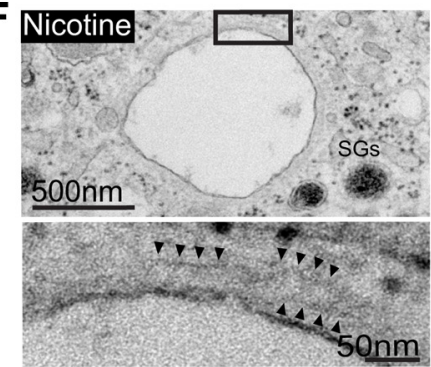

Lifeact

PH-PLC ס
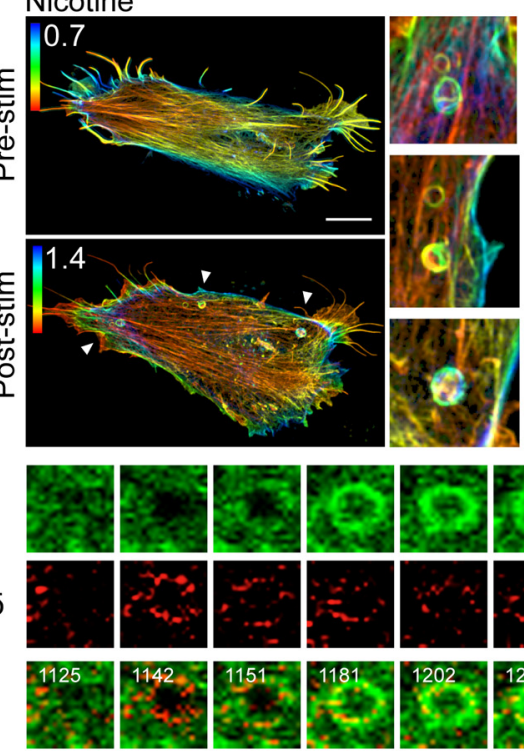

I Barium
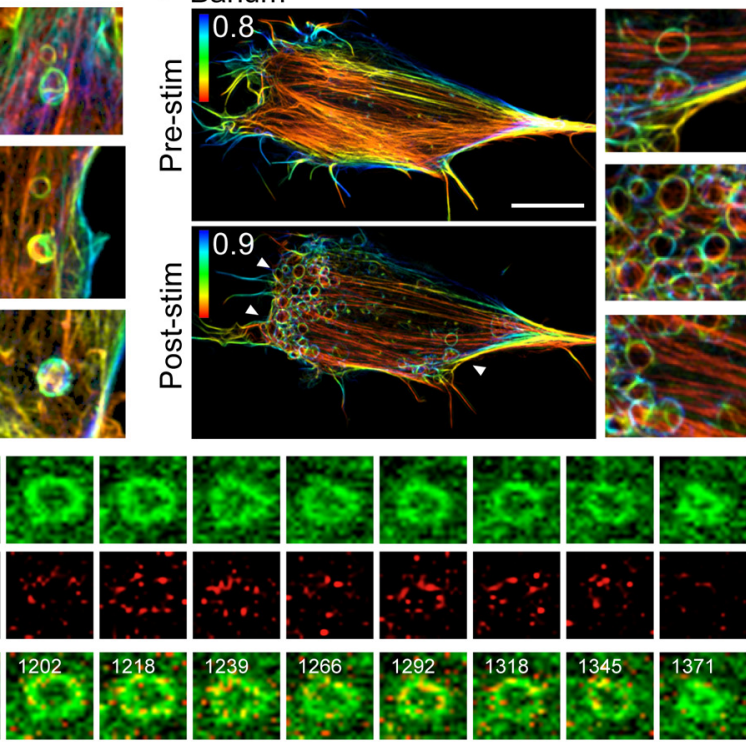

L

$\because$ PH-PLCס RFP

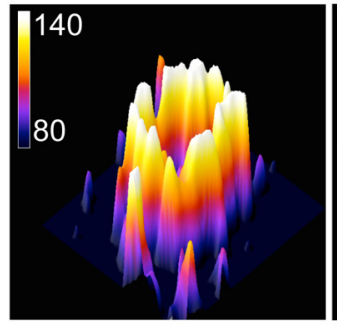

Lifeact

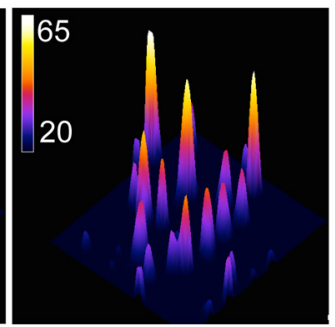

PH-PLCס $\rightarrow$ Lifeact-GFP

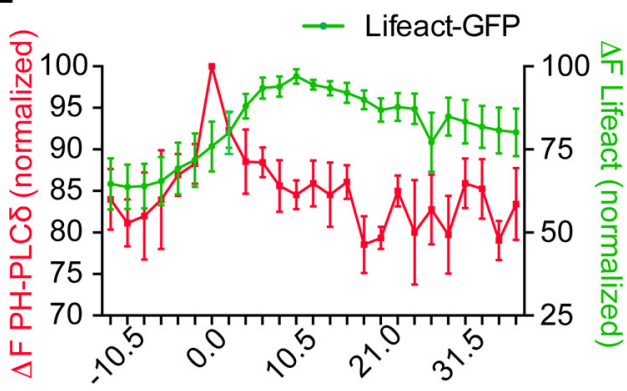

Time (s)

Figure 3. Ptdlns $(4,5) \mathrm{P}_{2}$ microdomains precede the appearance of actin rings. $A$, Bovine adrenal chromaffin cells transfected with Lifeact-GFP were imaged at the level of the footprint cortical actin network by time-lapse confocal microscopy before and during nicotine stimulation $(100 \mu \mathrm{m})$. Scale bar, $5 \mu \mathrm{m}$. The three panels are indicative of the change in the cortical actin network occurring during stimulation, including a partial depolymerization/remodeling followed by the appearance of actin rings in some areas. $\boldsymbol{B}$, Time series of a single actin ring from the cell shown in $\boldsymbol{A}$ highlighting its formation and constriction (time after stimulation in seconds is indicated in the panels). $(\mathbf{E}$, Quantitative analysis of actin ring size (C), duration (D), and time of appearance following the onset of stimulation $[E ; n=30$ rings from six cells $(\boldsymbol{C}, \boldsymbol{D}) ; n=75$ rings from six cells $(\boldsymbol{E})]$. $F$, Bovine chromaffin cells were treated with nicotine $(100 \mu \mathrm{m})$ for 2 min and were processed for electron microscopy. Nicotine stimulation triggered the appearance of large membrane-bound endosomes, a subset of which were surrounded by a detectable cytoskeleton (arrowheads). $\boldsymbol{G}$, Bovine chromaffin cells transfected with Lifeact-GFP were imaged following stimulation with either nicotine (100 $\mu \mathrm{M})$ in the presence or absence of cytochalasin (Figure legend continues.) 
2009). Using dextran, we first assessed whether bulk endocytosis could be induced in response to nicotine stimulation in cultured bovine chromaffin cells. Time-lapse confocal imaging of chromaffin cells bathed in a solution containing $70 \mathrm{kDa}$ tetramethyl rhodamine-conjugated dextran $(5 \mu \mathrm{M})$ during nicotine stimulation $(100 \mu \mathrm{M})$ showed a clear uptake of the probe into numerous large intracellular structures (Fig. 1A), an effect that was absent in unstimulated cells (Fig. 1A). We noted that the intracellular dextran-positive structures were mostly detected in the basal region, an area of the cell known to be actin rich (Trifaro et al., 2008). We next examined the effect of nicotine stimulation by electron microscopy and found the presence of large endocytic structures in stimulated cells (Fig. 1B). Some of these endocytic structures were still connected with the plasma membrane, as indicated by the presence of Ruthenium red staining applied during fixation (Fig. $1 B$, bottom). In view of the role of actin in bulk endocytosis (Nguyen et al., 2012), we next visualized actin network dynamics by repeating the dextran uptake experiments in chromaffin cells expressing Lifeact-GFP (Riedl et al., 2008), a 17 residue peptide fused to GFP that binds actin without altering neuroexocytosis in neurosecretory cells (Wen et al., 2011). We noted that all of the actin rings were dextran positive, but not all of the dextran-positive structures were surrounded by a ring of actin (Fig. $1 C, D$ ). Analysis of the temporal profile revealed that the dextran signal appeared slightly earlier than the actin ring (Fig. 1E). Importantly, as the actin rings appear to contract before disappearing and we observed dextran-positive structures lacking actin rings, we hypothesized that actin rings could contribute to reducing the diameter of the neck of budding endosomes before fission from the plasma membrane. In other words, we speculated that the dextran-positive structures lacking actin rings have been fully internalized by the cell, whereas the actin ringassociated structures are still in contact with the plasma membrane. To test this, we performed FRAP experiments. This revealed that most dextran-positive structures associated with rings exhibited full and fast recovery, consistent with immediate replacement of the dextran after photobleaching and denoting continuity of the dextran structure with the extracellular medium (Fig. $1 F$, top panels). We also noted that some dextran-positive structures associated with actin rings exhibited slower, albeit full fluorescence recovery, suggestive of a restricted access to the extracellular medium, perhaps due to the narrowing of the neck (Fig. $1 F$, middle panels). In contrast, dextran-positive structures lacking actin rings failed to recover following photobleaching, consistent with an endosome that was no longer in contact with

\section{$\leftarrow$}

(Figure legend continued.) $\quad \mathrm{D}\left(10 \mu \mathrm{M}, 30\right.$ min preincubation) or with $\mathrm{BaCl}_{2}(2 \mathrm{~mm})$, and the number of rings per cell was analyzed ( $n=6$ and $n=8$ cells, respectively). $\boldsymbol{H}, \boldsymbol{I}$, Bovine chromaffin cells transfected with Lifeact-GFP were imaged using SIM, and $z$-stack images were acquired before and after stimulation with either nicotine $(100 \mu \mathrm{m} ; \boldsymbol{H})$ or BaCl 2 (2 mm; $\boldsymbol{I})$. The color scale indicates the distance from the plasma membrane to the value indicated in the panels (micrometers in $z$-stack). Scale bar, $5 \mu \mathrm{m}$. J, Chromaffin cells cotransfected with Lifeact-GFP and PH-PLC $\delta$-RFP were time lapse imaged $(0.5 \mathrm{~Hz})$ during stimulation with nicotine $(100 \mu \mathrm{M})$. The panels show a region of interest highlighting the appearance of highly intense PH-PLC $\delta$-positive microdomains preceding an individual actin ring. $\boldsymbol{K}$, $3 \mathrm{D}$ surface plot of Lifeact-GFP ring and PH-PLC $\delta$ RFP-positive microdomains taken from $\mathbf{G} 1218$ s after stimulation. Note that the intensity of the actin ring appears to be continuous, whereas those of the $\operatorname{Ptdlns}(4,5) \mathrm{P}_{2}$ microdomains are discrete. $L$, Analysis of the time course of Lifeact-GFP and PH-PLC $\delta$-RFP fluorescence intensity at the level of identified actin rings. To measure the latency of actin ring formation, the peak intensity of PH-PLC $\delta$-RFP was used as a time reference, and its intensity as normalized. Note that the Ptdlns $(4,5) \mathrm{P}_{2}$ signal precedes actin ring formation ( $n=6$ rings from three cells). Error bars are mean \pm SEM. the extracellular medium (Fig. $1 F$, bottom panels). We confirmed the activity-dependent appearance of membrane invaginations by coexpressing GFP-GPI, a plasma membrane marker, and Lifeact-RFP (Fig. 2A). Consistent with the dextran experiments, the presence of actin rings was predictive of continuity between the plasma membrane and the GPI-positive endocytic structures (Fig. 2A-C).

\section{Characterization of the actin rings}

We next quantified the constriction and transient nature of the actin rings by performing time-lapse imaging of chromaffin cells expressing Lifeact-GFP alone. Before nicotine stimulation, actin was present at the basal plasma membrane region as actin stress filaments (Fig. 3A, left), as previously described (Wen et al., 2011). Following nicotine stimulation, we observed a slight reduction in Lifeact-GFP intensity, consistent with partial depolymerization (Fig. $3 A$, middle). This was followed by the appearance of actin ring structures (Fig. $3 A$, right). Time-lapse analysis of individual actin rings revealed that the diameter of the rings decreased over time (Fig. $3 A, C$ ), confirming their contractile nature. The average size and duration of the actin rings were $0.87 \pm 0.04 \mu \mathrm{m}$ and $2.22 \pm 0.15 \mathrm{~min}$, respectively (Fig. $3 D, E$ ), with the majority of rings appearing $7.03 \pm 0.32 \mathrm{~min}$ after the onset of nicotine stimulation. We noted that some cytoskeletal element surrounded the large endocytic structures as early as 2 min following the onset of nicotine stimulation by electron microscopy (Fig. $3 F$ ). The number and overall size and shape of these rings were similar in barium-stimulated cells (Fig. 3G), another highly potent secretagogue (Papadopulos et al., 2013). Consistent with a key role of actin remodeling, pretreatment of cells with cytochalasin-D $(10 \mu \mathrm{M})$ for $30 \mathrm{~min}$ inhibited the ring formation elicited by nicotine stimulation (Fig. $3 G$ ). Additionally, 3D high-resolution SIM imaging revealed that actin rings formed following stimulation with either secretagogue were located just above the level of the cortical actin network, as indicated by the difference in color coding between the stress fibers and abutting rings (Fig. $3 H, I$ ).

As PtdIns $(4,5) \mathrm{P}_{2}$ is a major modulator of actin remodeling (Lassing and Lindberg, 1985; Saarikangas et al., 2010; Wen et al., 2011), we tested whether PtdIns $(4,5) \mathrm{P}_{2}$ could initiate the formation of these actin rings. The $\operatorname{PtdIns}(4,5) \mathrm{P}_{2}$-selective pleckstrin homology domain of PH-PLC $\delta$-RFP was coexpressed with Lifeact-GFP in chromaffin cells. Following nicotine stimulation, PH-PLC $\delta$ recruitment was detected $9.8 \pm 2.5 \mathrm{~s}$ before actin ring formation (Fig. $3 J-L)$. The appearance of $\operatorname{PtdIns}(4,5) \mathrm{P}_{2}$ before that of actin rings suggests that $\operatorname{PtdIns}(4,5) \mathrm{P}_{2}$ acts upstream by promoting actin nucleation at the site of nascent endosome formation.

\section{Myosin II is involved in actin ring formation}

The contractile nature of the actin rings suggested the involvement of molecular motors, such as myosin II, where it can crosslink actin filaments, and exert tension in both muscle and nonmuscle cells (for review, see Berg et al., 2001). Furthermore, myosin II is a key player in other types of contractile rings, such as those that occur during cell division (Yumura et al., 2008; Uehara et al., 2010), and stimulated chromaffin cells exhibited numerous phalloidin-positive ring structures that directly colocalized with myosin IIA and IIB (Fig. $4 A, B$ ).

Using the myosin II-specific inhibitor blebbistatin, we found a significant reduction in the number of Lifeact-positive rings that failed to contract during the time course of our experiment (Fig. $5 A-D)$. Not surprisingly, the number of dextran-positive structures was also significantly reduced by myosin II inhibition (Fig. 
A

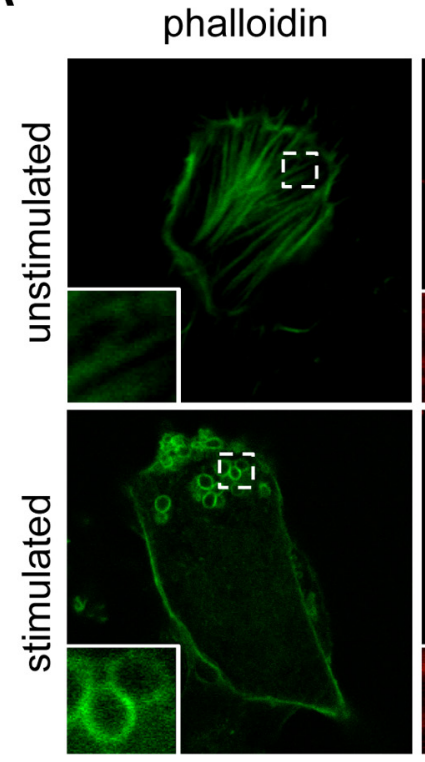

B

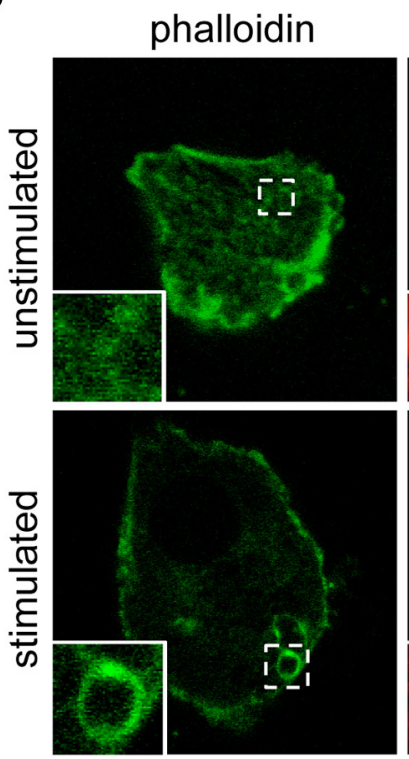

myosin Ila
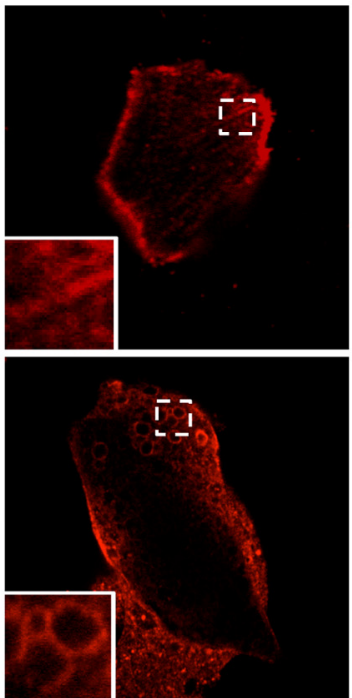

myosin Ilb
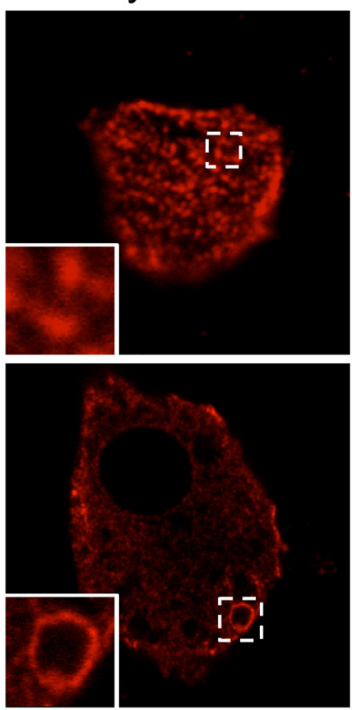

merge

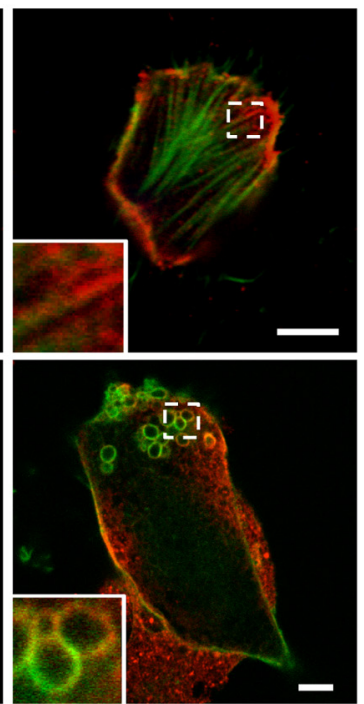

merge
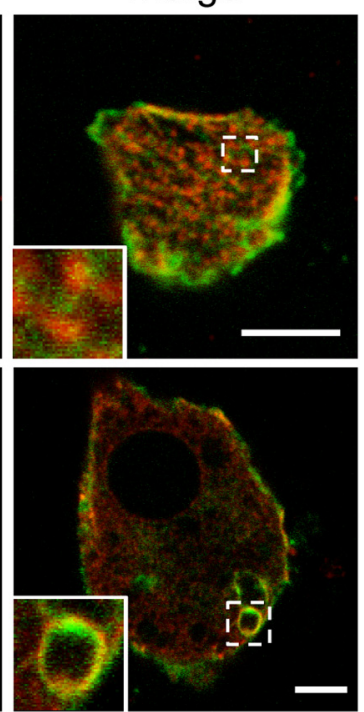

Figure 4. Myosin lla and Illb localize to actin rings. $A, B$, Resting and nicotine-stimulated ( $100 \mu \mathrm{m}$ for $8 \mathrm{~min}$ ) bovine adrenal chromaffin cells were fixed and stained for either myosin $\mathrm{ll}(\boldsymbol{A})$ or myosin $\mathrm{llb}(\boldsymbol{B})$ and phalloidin-Alexa Fluor 488. Insets illustrate the presence of myosin Illa and IIb associating with actin at rest (top panels) and in actin ring structures after stimulation (bottom panels). Scale bars, $5 \mu \mathrm{m}$.

$5 E, F)$. FRAP analysis of the few dextran-positive structures that were present resulted in either (1) immediate recovery or (2) slower recovery of fluorescence indicating continuity with the plasma membrane in both cases (Fig. $5 G$ ). Consistent with the dextran experiments, FRAP analysis of GFP-GPI was also indicative of a continuity between endocytic structures and the plasma membrane (Fig. 5H).

Our data point to a role of contractile actin rings before fission of the nascent bulk endosome. We hypothesize that the contractile actin ring could narrow the neck of the budding endosome, thereby contributing to the initiation of dynamin recruitment and fission activity. To test this hypothesis, we used the potent dynamin inhibitor Dyngo4a (Harper et al., 2011; McCluskey et al., 2013). Dyngo4a treatment reduced the number of dextran-positive structures, which all remained connected to the plasma membrane, as revealed by FRAP experiments (Fig. 6A-C). Time-lapse imaging of Lifeact-GFP also revealed a reduction in the number of actin rings elicited by secretagogue stimulation (Fig. 6D,E). Interestingly, the few rings that formed under Dyngo4a treatment remained stable and failed to contract throughout the experiment (Fig. $6 F, G$ ). We also tested the effect of expressing dynamin-2 (K44A) dominant-negative in chromaffin cells and found that the number of dextran-positive structures were significantly reduced (Fig. 6H) to a level comparable to Dyngo4a-treated cells. These data not only indicate that dynamin promotes effective fission of bulk endosomes from the plasma membrane, but also suggest an involvement of dynamin in the formation and contractility of the actin rings.

\section{Discussion}

In this study, we demonstrate that, as in neurons, neurosecretory cells undergo bulk endocytosis in response to secretagogue stimulation. This has allowed us to identify a molecular mechanism whereby actin and dynamin actively cooperate to form actomyosin II rings that are capable of narrowing the neck of budding bulk endosomes before fission from the plasma membrane (Fig. 6I).

Together with CME and kiss-and-run, $\mathrm{ADBE}$ is emerging as a major contributor to synaptic vesicle recycling in nerve terminals (Clayton et al., 2007, 2008; Wu and Wu, 2007; Nguyen et al., 2012). A number of key proteins has been shown to be critical for ADBE in neurons. These include syndapin (Clayton et al., 2009), calcineurin (Evans and Cousin, 2007), actin (Kuromi and Kidokoro, 1998; Holt et al., 2003; Richards et al., 2004; Nguyen et al., 2012), dynamin (Ferguson et al., 2007; Clayton et al., 2009, 2010; Nguyen et al., 2012), and, more recently, myosin II (Flores et al., 2014). Our study demonstrates a clear role for dynamin in the generation of acto-myosin II rings and the fission of budding bulk endosomes. These results are in good agreement with the established role for dynamin in ADBE and in actin polymerization (Kessels et al., 2001; Gu et al., 2010).

We used a potent dynamin inhibitor, Dyngo4a (Howes et al., 2010; Harper et al., 2011; McCluskey et al., 2013), which is not isoform specific and has potential off-target effects (Park et al., 2013). However, our data were corroborated with a dominant-negative approach strongly pointing to a key role for dynamin in this process (Harper et al., 2013). Further studies to identify the dynamin isoform involved would need to be performed in light of the recent study (González-Jamett et al., 2013) suggesting that dynamin 2 may be the predominant isoform in neurosecretory cells despite dynamin I being neuron specific. Further work will also be needed to establish whether syndapin and calcineurin are required for bulk endocytosis in neurosecretory cells. 
A

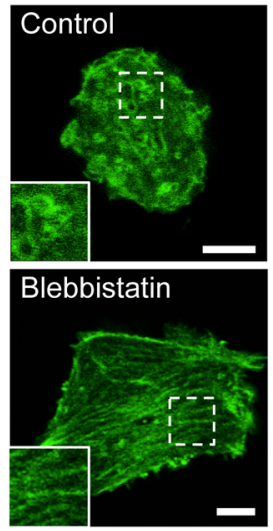

B

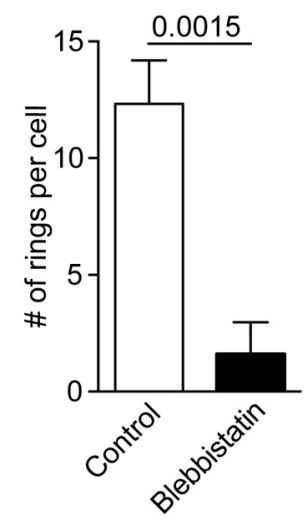

D

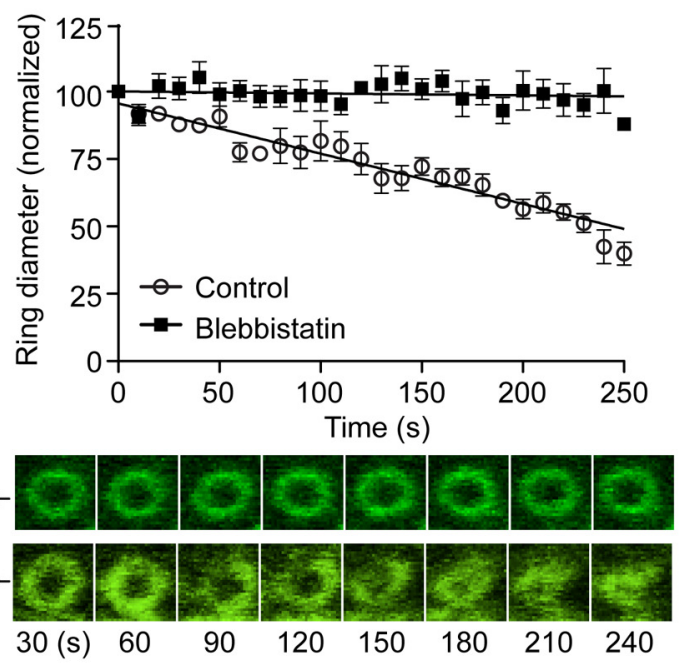

G

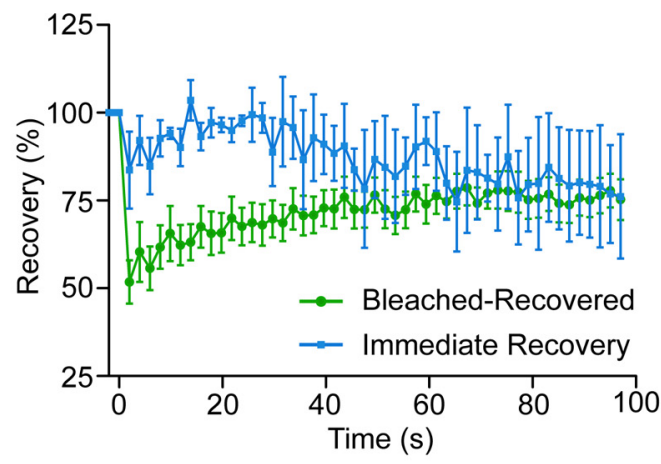

C

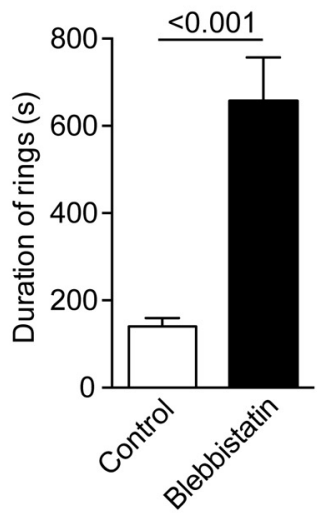

E

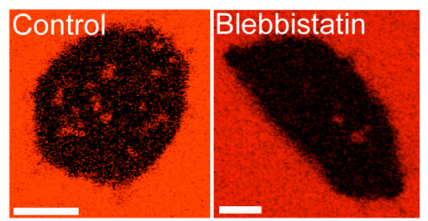

$\mathbf{F}$

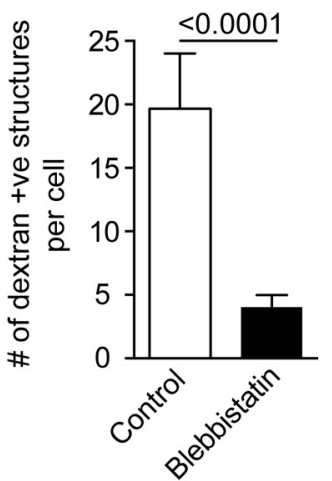

H

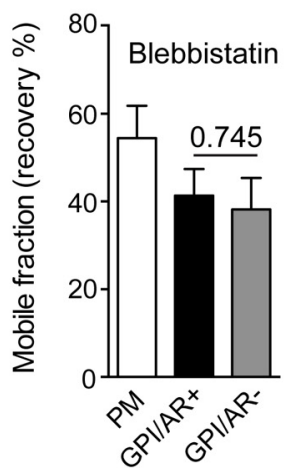

Figure 5. Inhibition of myosin II with blebbistatin interferes with actin ring formation and constriction, and prevents dextranpositive endosomal fission. $\boldsymbol{A}-\boldsymbol{D}$, Bovine adrenal chromaffin cells transfected with Lifeact-GFP were stimulated with nicotine (100 $\mu \mathrm{m}$ ) in the presence or absence of blebbistatin (10 min preincubation at $10 \mu \mathrm{m}$ ) and imaged by time-lapse confocal microscopy at the level of the footprint. $A$, Representative confocal image of the cortical actin network of a chromaffin cell before (prestimulation) and $8 \mathrm{~min}$ after nicotine stimulation (poststimulation) with or without blebbistatin. Note that blebbistatin prevents the formation of actin rings. Scale bar, $5 \mu \mathrm{m}$. Analysis of the number of rings formed per cell ( $\boldsymbol{B}$; six control cells; five blebbistatin-treated cells) and their duration ( $\boldsymbol{C} ; n=52$ rings from eight control cells; $n=14$ rings from four blebbistatin-treated cells) and their rate of constriction ( $\boldsymbol{D} ; n=10$ rings from three control cells; $n=6$ rings from two blebbistatin-treated cells). Note that blebbistatin significantly blocks the formation of rings and prevents their constriction. As a result, the few rings that form fail to constrict. $\boldsymbol{E}$, Chromaffin cells transfected with Lifeact-GFP were incubated with $70 \mathrm{kDa}$ dextran-TMRh and were stimulated with nicotine (100 $\mu \mathrm{M}$ ) in the presence or absence of blebbistatin (10 min preincubation at $10 \mu \mathrm{m}$ ) and imaged by time-lapse confocal microscopy at the level of the footprint. Scale bar, $5 \mu \mathrm{m}$. $\boldsymbol{F}$, Analysis of the number of dextran-positive structures following stimulation ( $n=6$ control cells and $n=21$ blebbistatin-treated cells). G, Dextran-positive structures formed following stimulation in the presence of blebbistatin were photobleached using 100\% laser (20 iterations) and were time lapse imaged at $0.5 \mathrm{~Hz}$. All dextran-positive

Although actin is involved in countless cellular processes including exocytosis (Torregrosa-Hetland et al., 2011; Wen et al., 2011), its function in constricting rings has been described in only a few instances such as cytokinesis, whereby an acto-myosin ring forms at the cleavage furrow before cell division (Cao and Wang, 1990; Pelham and Chang, 2001). Actin rings have also been described in exocytosis of von Willebrand factor from Weibel-Palade bodies (Nightingale et al., 2011). As far as a role in endocytosis is concerned, Shupliakov et al. (2002) observed actin rings surrounding synaptic vesicle clusters in lamprey reticulospinal synapses and concluded that the actin was actively involved in vesicle recycling in the adjacent endocytic zones. However, to the best of our knowledge, although actin polymerization is known to be essential for bulk endocytosis (Kuromi and Kidokoro, 1998; Holt et al., 2003; Richards et al., 2004; Nguyen et al., 2012), no mechanistic model involving a constricting actin ring has been proposed to far. The actin rings described in our study explain for the first time how the neck of budding endosomes narrows to allow the fission machinery to be recruited and become active. Importantly, even though actin, myosin II, and dynamin have been shown to be major players in ADBE in both neurons and chromaffin cells, the fact that the onset of ADBE in neurosecretory cells is delayed could highlight some mechanistic differences, particularly with regard to ring formation. More work is therefore needed to verify whether our model also applies to ADBE in nerve terminals.

We hypothesized that $\operatorname{PtdIns}(4,5) \mathrm{P}_{2}$ could have a role in $\mathrm{ADBE}$ as this process can be blocked in neurons by pan PI3 kinase inhibitors (Holt et al., 2003; Gaffield et al., 2011), and because $\operatorname{PtdIns}(4,5) \mathrm{P}_{2}$ can act to recruit and anchor actin barbed end nucleating factors such as N-WASP, Arp2/3, and cdc42 (Ma et al., 1998; Rohatgi et al., 1999), thereby initiating actin polymerization. Our time-lapse imaging using the PtdIns $(4,5) \mathrm{P}_{2}$ fluorescent probe

\section{$\leftarrow$}

structures fully recovered their fluorescence, indicating persisting continuity with the extracellular dextran ( $n=11$ BleachedRecovered dextran-positive structures from three cells; $n=3$ Immediate Recovery dextran-positive structures from three cells). $\boldsymbol{H}$, Plasma membrane portions of the cell were used as a control for recovery. GPI-positive rings that were also positive for Lifeact-RFP actin ring GPI/AR - rings were able to recover to the same extent as GPI/AR + ringsfollowing blebbistatin pretreatment $(p>0.05$, $n s ; n=6$ cells). Error bars are mean \pm SEM. 
A

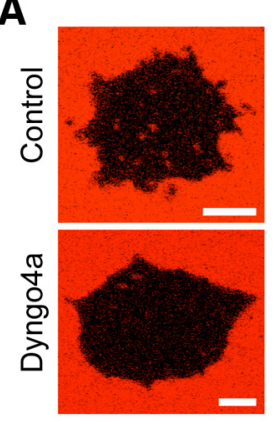

B

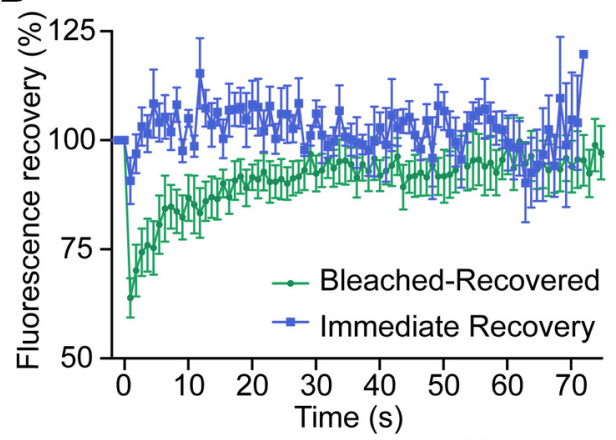

C

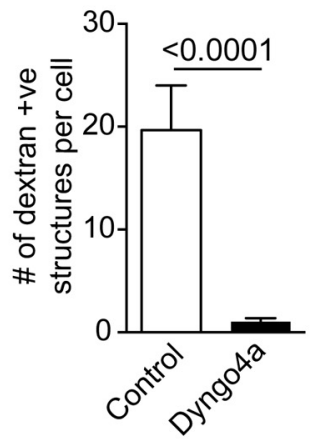

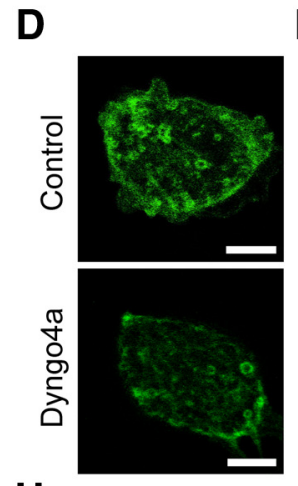

H

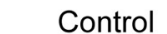

E

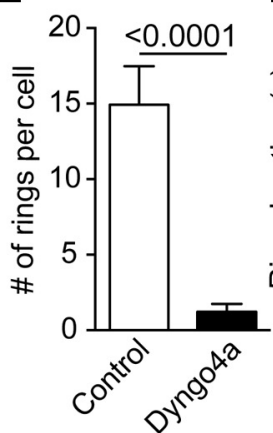

$F$

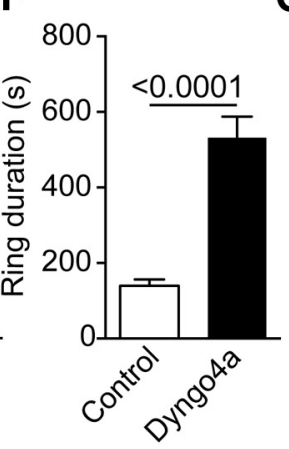

G
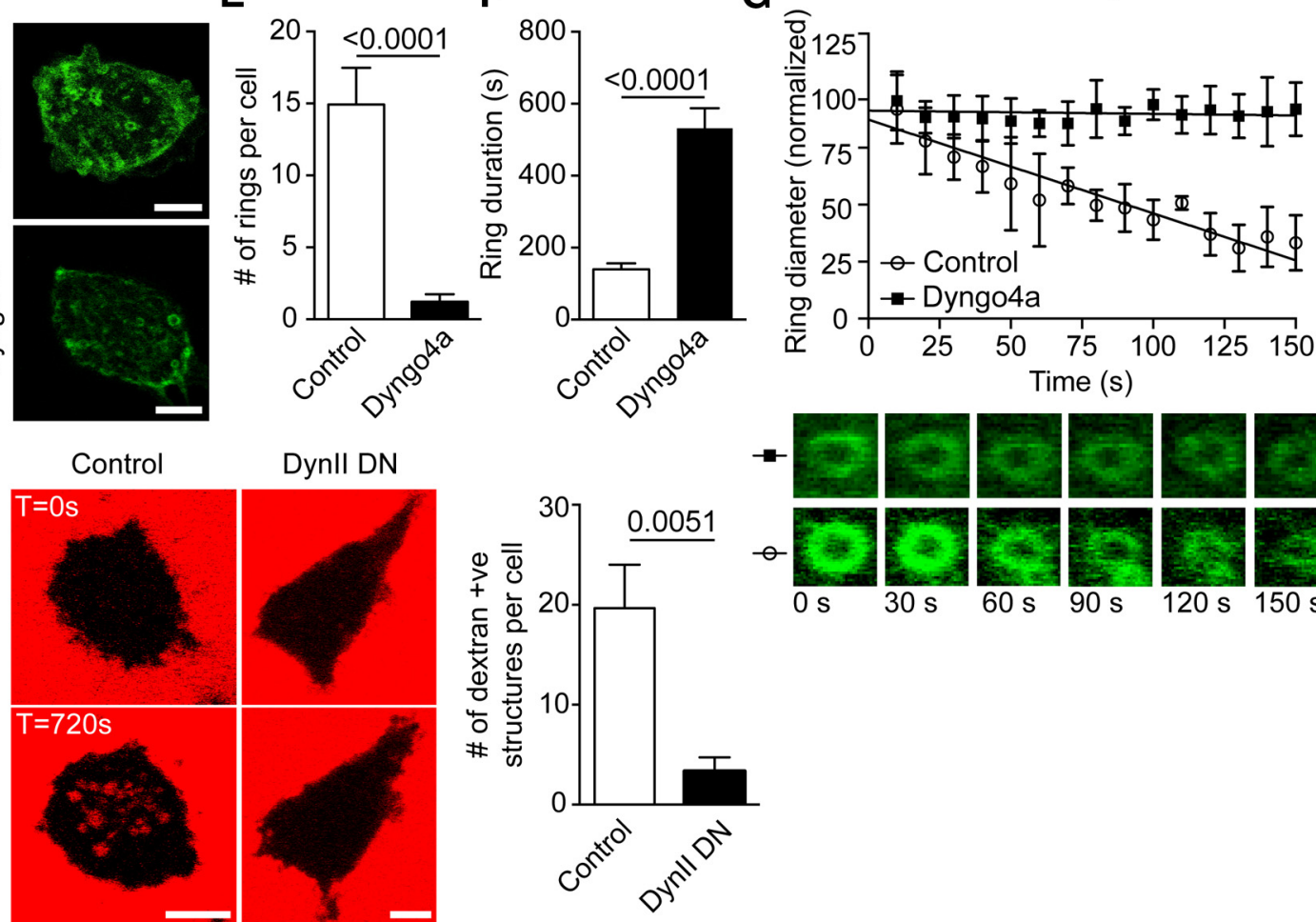

\section{Dynll DN}
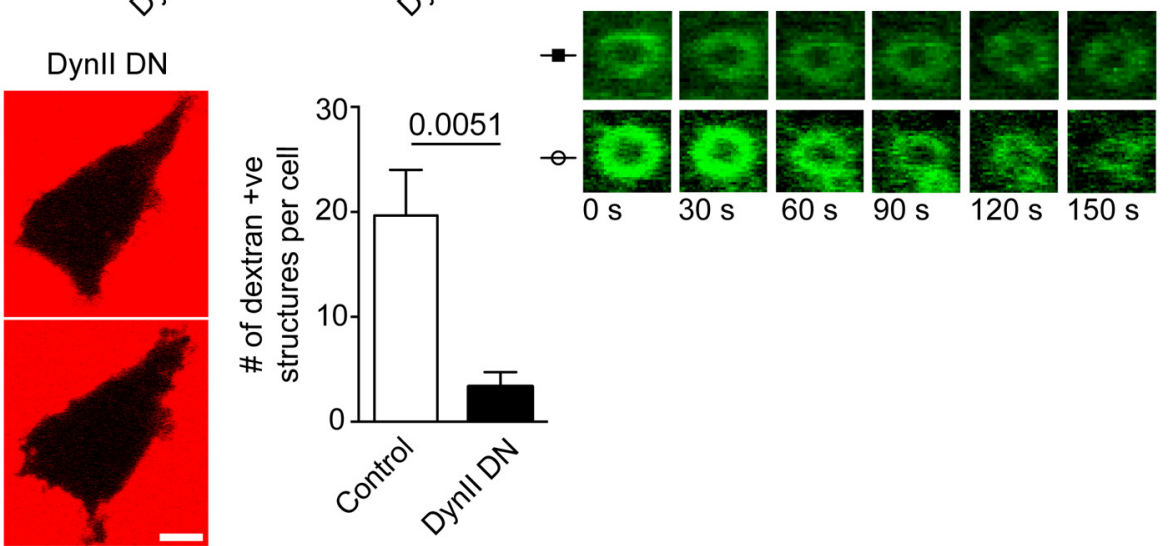

I

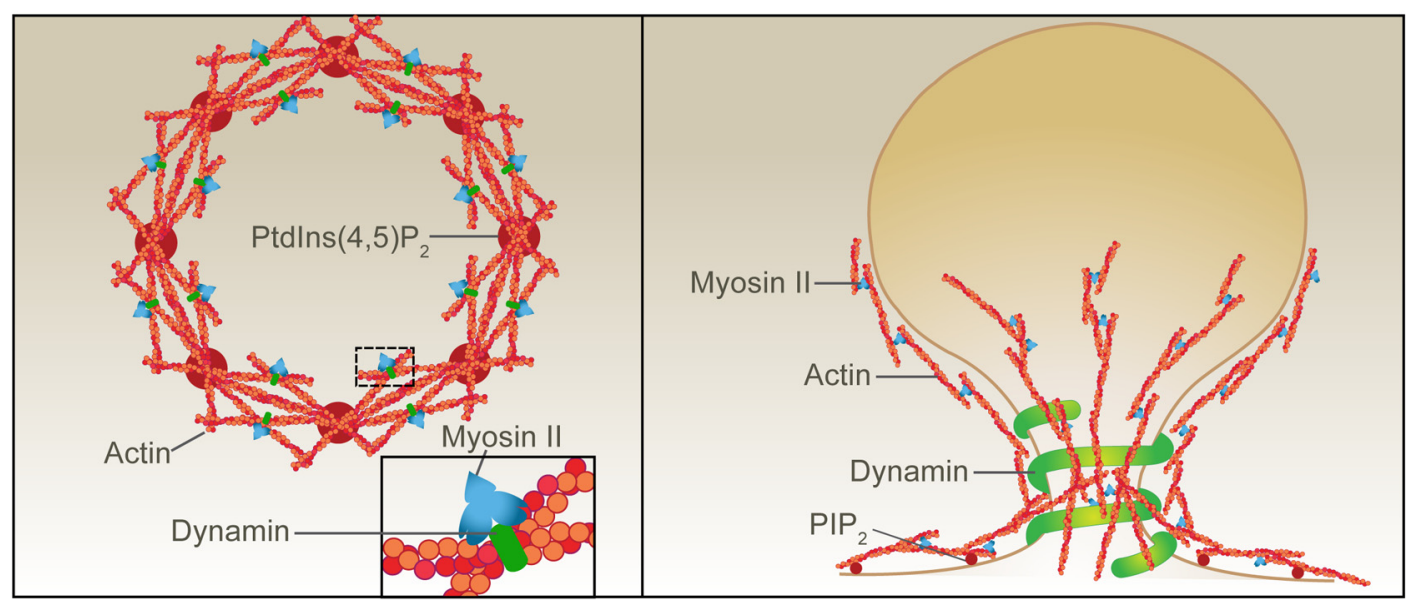

Figure 6. Dynamin inhibition prevents actin ring formation and dextran-positive endosomal fission. $A$, Bovine adrenal chromaffin cells were incubated with $70 \mathrm{kDa}$ dextran-TMRh in the presence or absence of Dyngo4a (30 $\mu \mathrm{M}$ ) and were imaged by time-lapse confocal microscopy during nicotine stimulation (100 $\mu \mathrm{M})$. Scale bar, $5 \mu \mathrm{m}$. $\boldsymbol{B}$, Dextran-positive structures formed following stimulation in the presence of Dyng04a were photobleached using $100 \%$ laser stimulation (20 iterations) and were time lapse imaged at $0.5 \mathrm{~Hz}$. All dextran-positive structures fully recovered their fluorescence, indicating persisting continuity with the extracellular dextran ( $n=7$ Bleached-Recovered dextran-positive structures from four cells; $n=5 \mathrm{Immediate}$ Recovery dextran-positive structures from three cells). C, Analysis of the number of dextran-positive structures appearing following stimulation ( $n=6$ control cells and $n=29$ Dyngo4a-treated cells). $\boldsymbol{D}$, Chromaffin cells transfected with Lifeact-GFP were stimulated with nicotine $(100 \mu \mathrm{M})$ in the presence or absence of Dyngo4a (30 $\mu \mathrm{m})$ and were imaged by time-lapse confocal microscopy. Scale bar, $5 \mu \mathrm{m}$. $\boldsymbol{E}-\boldsymbol{G}$, Analysis of the number of rings formed per cell $(\boldsymbol{E} ; n=12$ control cells; $n=35$ Dyng04a-treated cells), their duration ( $\boldsymbol{F} ; n=52$ rings from 8 control cells; $n=20$ rings from 4 Dyngo4a-treated cells), and their rate of constriction ( $G ; n=4$ rings from 3 control cells; $n=4$ rings from 2 Dyngo4a-treated cells). Note that Dyngo4a significantly blocks the number of (Figure legend continues.) 
PH-PLC $\delta$ suggests an involvement of PtdIns $(4,5) \mathrm{P}_{2}$ in generating the acto-myosin II rings. Consistent with an initiating role of PtdIns $(4,5) \mathrm{P}_{2}$, we detect an array of PtdIns $(4,5) \mathrm{P}_{2}$ microdomains that precedes the generation of the actin ring. These $\operatorname{PtdIns}(4,5) \mathrm{P}_{2}$ hotspots are located at strategic points of the impending actin ring, and it is tempting to speculate that they represent multiple points of actin nucleation and that myosin II and dynamin may be actively involved in cross-linking these streams of growing filaments, thereby stabilizing the actin ring (Fig. $6 I$ ). PtdIns $(4,5) \mathrm{P}_{2}$ is also present and required for the correct organization of the cleavage furrow, and has a role in adhesion between the contractile ring and the plasma membrane (Field et al., 2005; Liu et al., 2012).

Our data also point to a role of dynamin and myosin II in inducing actin ring formation. Indeed, pharmacological inhibition of dynamin and myosin II drastically reduced the actual number of acto-myosin II rings (Figs. 5, 6). Further, along with the well established role of dynamin in mediating membrane fission, a number of studies (Kessels et al., 2001; Gu et al., 2010) have shown that dynamin can directly interact with actin and regulate its polymerization. Our data are therefore consistent with an additional role of dynamin in polymerizing specific pools of actin to form rings.

Our results demonstrate that the contractility of the actin ring can be blocked by pharmacological inhibition of myosin II (Fig. 5). The critical role of myosin II in cell division as a force-generating fission mechanism has two current hypotheses. In the classic model, bipolar myosin II filaments move along F-actin in a similar manner to that of the muscle sarcomere (Egelhoff et al., 1993). In the alternative model, depolymerization of the cross-linked actin network does not drive constriction because many actin filaments of the cytokinesis ring are not oriented in the plane of division (Kruse and Julicher, 2003; Reichl et al., 2008). More work will be needed to determine which model best suits the constriction of activitydependent actin rings involved in ADBE. On another note, myosin II and dynamin have been implicated in the fusion pore formation (Berberian et al., 2009; Chan et al., 2010; González-Jamett et al., 2013), and altering the dynamics of the fusion pore could have secondary effects on the mode of endocytosis elicited.

It is worth noting that dynamin inhibition also affects ring contractility, suggesting a possible role in acto-myosin II constriction. In this view dynamin II was shown to coordinate actomyosin II interaction in epithelial cells (Chua et al., 2009).

Regardless of the molecular underpinning of actin ring constriction, our study is the first to demonstrate that actin ring constriction is critical to driving bulk endocytosis to completion. Indeed, we show that inhibition of either myosin II or dynamin function leads to a defect in dextran internalization and the failure of fission from the plasma membrane (Figs. 5, 6).

It should be noted that our interpretation of the FRAP data is based on the principle that a fully "detached" nascent bulk endo-

\section{$\leftarrow$}

(Figure legend continued.) ring forming and prevent their constriction. $\boldsymbol{H}$, Chromaffin cells transfected with dynamin II (K44A) dominant-negative mutant were incubated with $70 \mathrm{kDa}$ dextran-TMRh and incubated with or without nicotine $(100 \mu \mathrm{M})$ while being imaged by timelapse confocal microscopy at the level of the footprint (surface area in contact with the coverslip). Numerous internal dextran-positive structures appeared after stimulation in control but are significantly reduced in cells expressing Dynamin mutant. Scale bars, $5 \mu \mathrm{m}$. I, Left, Model highlighting the initiating role of $\operatorname{Ptdlns}(4,5) \mathrm{P}_{2}$ in generating actin filaments from regularly spaced hotspots in the plasma membrane delineating the future actin ring. In this model, myosin II and dynamin stabilize the actin ring by cross-linking the intersecting fibers (inset). Right, Model highlighting the role of actin rings in generating bulk endosomes. Myosin II and dynamin play critical roles in generating and stabilizing the actin ring in addition to the role of dynamin in pinching off the nascent bulk endosomes from the plasma membrane. some is unable to recover fluorescence following photobleaching as it is spatially separated from any other source of dextran. We cannot rule out the possibility that bulk endosomes could fuse with other dextran-containing organelles. However, high-molecularweight dextran is only internalized in bulk endosomes that are not being re-released upon secondary stimulation in neurons, ruling out the potential contribution of the CME pathway (Clayton and Cousin, 2009). Bulk endosome homotypic fusion could also theoretically contribute to the fluorescence recovery. However, we did not observe any noticeable morphological change in the size or shape of the dextran-positive endosomes, and the associated actin rings were always relatively immobile, strongly suggesting that they were in close contact with the plasma membrane as they appear to originate from the plane of remodeled cortical actin network after stimulation (Fig. $3 \mathrm{H}, I$ ).

In conclusion, we demonstrate that constricting acto-myosin II rings appearing following stimulation are critical for the fission of bulk endosomes from the plasma membrane in neurosecretory cells. In this context, PtdIns $(4,5) \mathrm{P}_{2}$, actin, myosin II, and dynamin provide a molecular framework on which to build a more comprehensive picture of the mechanism underpinning bulk endocytosis. Revealing bulk endocytosis in neurosecretory cells may lead to further understanding of the molecular mechanism driving $\mathrm{ADBE}$ in other cellular systems.

\section{References}

Berberian K, Torres AJ, Fang Q, Kisler K, Lindau M (2009) F-actin and myosin II accelerate catecholamine release from chromaffin granules. J Neurosci 29:863-870. CrossRef Medline

Berg JS, Powell BC, Cheney RE (2001) A millennial myosin census. Mol Biol Cell 12:780-794. CrossRef Medline

Cao LG, Wang YL (1990) Mechanism of the formation of contractile ring in dividing cultured animal cells. II. Cortical movement of microinjected actin filaments. J Cell Biol 111:1905-1911. CrossRef Medline

Ceridono M, Ory S, Momboisse F, Chasserot-Golaz S, Houy S, Calco V, Haeberlé AM, Demais V, Bailly Y, Bader MF, Gasman S (2011) Selective recapture of secretory granule components after full collapse exocytosis in neuroendocrine chromaffin cells. Traffic 12:72-88. CrossRef Medline

Chan SA, Doreian B, Smith C (2010) Dynamin and myosin regulate differential exocytosis from mouse adrenal chromaffin cells. Cell Mol Neurobiol 30:1351-1357. CrossRef Medline

Chua J, Rikhy R, Lippincott-Schwartz J (2009) Dynamin 2 orchestrates the global actomyosin cytoskeleton for epithelial maintenance and apical constriction. Proc Natl Acad Sci USA 106:20770-20775. CrossRef Medline

Clayton EL, Cousin MA (2009) Quantitative monitoring of activitydependent bulk endocytosis of synaptic vesicle membrane by fluorescent dextran imaging. J Neurosci Methods 185:76-81. CrossRef Medline

Clayton EL, Evans GJ, Cousin MA (2007) Activity-dependent control of bulk endocytosis by protein dephosphorylation in central nerve terminals. J Physiol 585:687-691. CrossRef Medline

Clayton EL, Evans GJ, Cousin MA (2008) Bulk synaptic vesicle endocytosis is rapidly triggered during strong stimulation. J Neurosci 28:6627-6632. CrossRef Medline

Clayton EL, Anggono V, Smillie KJ, Chau N, Robinson PJ, Cousin MA (2009) The phospho-dependent dynamin-syndapin interaction triggers activity-dependent bulk endocytosis of synaptic vesicles. J Neurosci 29: 7706-7717. CrossRef Medline

Clayton EL, Sue N, Smillie KJ, O'Leary T, Bache N, Cheung G, Cole AR, Wyllie DJ, Sutherland C, Robinson PJ, Cousin MA (2010) Dynamin I phosphorylation by GSK3 controls activity-dependent bulk endocytosis of synaptic vesicles. Nat Neurosci 13:845-851. CrossRef Medline

Egelhoff TT, Lee RJ, Spudich JA (1993) Dictyostelium myosin heavy chain phosphorylation sites regulate myosin filament assembly and localization in vivo. Cell 75:363-371. CrossRef Medline

Evans GJ, Cousin MA (2007) Activity-dependent control of slow synaptic vesicle endocytosis by cyclin-dependent kinase 5. J Neurosci 27:401-411. CrossRef Medline

Ferguson SM, Brasnjo G, Hayashi M, Wölfel M, Collesi C, Giovedi S, Raimondi A, Gong LW, Ariel P, Paradise S, O'toole E, Flavell R, Cremona O, 
Miesenböck G, Ryan TA, De Camilli P (2007) A selective activitydependent requirement for dynamin 1 in synaptic vesicle endocytosis. Science 316:570-574. CrossRef Medline

Field SJ, Madson N, Kerr ML, Galbraith KA, Kennedy CE, Tahiliani M, Wilkins A, Cantley LC (2005) PtdIns(4,5)P2 functions at the cleavage furrow during cytokinesis. Curr Biol 15:1407-1412. CrossRef Medline

Flores JA, Balseiro-Gomez S, Cabeza JM, Acosta J, Ramirez-Ponce P, Ales E (2014) A new role for myosin II in vesicle fission. PLoS One 9:e100757. CrossRef Medline

Gaffield MA, Romberg CF, Betz WJ (2011) Live imaging of bulk endocytosis in frog motor nerve terminals using FM dyes. J Neurophysiol 106:599607. CrossRef Medline

González-Jamett AM, Momboisse F, Guerra MJ, Ory S, Baez-Matus X, Barraza N, Calco V, Houy S, Couve E, Neely A, Martínez AD, Gasman S, Cárdenas AM (2013) Dynamin-2 regulates fusion pore expansion and quantal release through a mechanism that involves actin dynamics in neuroendocrine chromaffin cells. PLoS One 8:e70638. CrossRef Medline

Gu C, Yaddanapudi S, Weins A, Osborn T, Reiser J, Pollak M, Hartwig J, Sever S (2010) Direct dynamin-actin interactions regulate the actin cytoskeleton. EMBO J 29:3593-3606. CrossRef Medline

Harper CB, Martin S, Nguyen TH, Daniels SJ, Lavidis NA, Popoff MR, Hadzic G, Mariana A, Chau N, McCluskey A, Robinson PJ, Meunier FA (2011) Dynamin inhibition blocks botulinum neurotoxin type-A endocytosis in neurons and delays botulism. J Biol Chem 286:35966-35976. CrossRef Medline

Harper CB, Popoff MR, McCluskey A, Robinson PJ, Meunier FA (2013) Targeting membrane trafficking in infection prophylaxis: dynamin inhibitors. Trends Cell Biol 23:90-101. CrossRef Medline

Holt M, Cooke A, Wu MM, Lagnado L (2003) Bulk membrane retrieval in the synaptic terminal of retinal bipolar cells. J Neurosci 23:1329-1339. Medline

Howes MT, Mayor S, Parton RG (2010) Molecules, mechanisms, and cellular roles of clathrin-independent endocytosis. Curr Opin Cell Biol 22: 519-527. CrossRef Medline

Kessels MM, Engqvist-Goldstein AE, Drubin DG, Qualmann B (2001) Mammalian Abpl, a signal-responsive F-actin-binding protein, links the actin cytoskeleton to endocytosis via the GTPase dynamin. J Cell Biol 153:351-366. CrossRef Medline

Kruse K, Jülicher F (2003) Self-organization and mechanical properties of active filament bundles. Phys Rev E Stat Nonlin Soft Matter Phys 67: 051913. CrossRef Medline

Kuromi H, Kidokoro Y (1998) Two distinct pools of synaptic vesicles in single presynaptic boutons in a temperature-sensitive Drosophila mutant, shibire. Neuron 20:917-925. CrossRef Medline

Lassing I, Lindberg U (1985) Specific interaction between phosphatidylinositol 4,5-bisphosphate and profilactin. Nature 314:472-474. CrossRef Medline

Liu J, Fairn GD, Ceccarelli DF, Sicheri F, Wilde A (2012) Cleavage furrow organization requires PIP(2)-mediated recruitment of anillin. Curr Biol 22:64-69. CrossRef Medline

Ma L, Rohatgi R, Kirschner MW (1998) The Arp2/3 complex mediates actin polymerization induced by the small GTP-binding protein Cdc42. Proc Natl Acad Sci USA 95:15362-15367. CrossRef Medline

Martin S, Tomatis VM, Papadopulos A, Christie MP, Malintan NT, Gormal RS, Sugita S, Martin JL, Collins BM, Meunier FA (2013) The Munc18-1 domain 3a loop is essential for neuroexocytosis but not for syntaxin-1A transport to the plasma membrane. J Cell Sci 1:2353-2360. CrossRef Medline

McCluskey A, Daniel JA, Hadzic G, Chau N, Clayton EL, Mariana A, Whiting A, Gorgani NN, Lloyd J, Quan A, Moshkanbaryans L, Krishnan S, Perera S, Chircop M, von Kleist L, McGeachie AB, Howes MT, Parton RG, Campbell M, Sakoff JA, et al. (2013) Building a better dynasore: the dyngo compounds potently inhibit dynamin and endocytosis. Traffic 14: 1272-1289. CrossRef Medline

Meunier FA, Feng ZP, Molgó J, Zamponi GW, Schiavo G (2002) Glycerotoxin from Glycera convoluta stimulates neurosecretion by up-regulating N-type Ca2 + channel activity. EMBO J 21:6733-6743. CrossRef Medline

Meunier FA, Osborne SL, Hammond GR, Cooke FT, Parker PJ, Domin J, Schiavo G (2005) Phosphatidylinositol 3-kinase C2alpha is essential for ATP-dependent priming of neurosecretory granule exocytosis. Mol Biol Cell 16:4841-4851. CrossRef Medline

Miller TM, Heuser JE (1984) Endocytosis of synaptic vesicle membrane at the frog neuromuscular junction. J Cell Biol 98:685-698. CrossRef Medline

Nguyen TH, Maucort G, Sullivan RK, Schenning M, Lavidis NA, McCluskey
A, Robinson PJ, Meunier FA (2012) Actin- and dynamin-dependent maturation of bulk endocytosis restores neurotransmission following synaptic depletion. PLoS One 7:e36913. CrossRef Medline

Nightingale TD, White IJ, Doyle EL, Turmaine M, Harrison-Lavoie KJ, Webb KF, Cramer LP, Cutler DF (2011) Actomyosin II contractility expels von Willebrand factor from Weibel-Palade bodies during exocytosis. J Cell Biol 194:613-629. CrossRef Medline

Papadopulos A, Martin S, Tomatis VM, Gormal RS, Meunier FA (2013) Secretagogue stimulation of neurosecretory cells elicits filopodial extensions uncovering new functional release sites. J Neurosci 33:19143-19153. CrossRef Medline

Park Rj, Shen H, Liu L, Liu X, Ferguson SM, De Camilli P (2013) Dynamin triple knockout cells reveal off target effects of commonly used dynamin inhibitors. J Cell Sci 126:5305-5312. CrossRef Medline

Pelham RJ Jr, Chang F (2001) Role of actin polymerization and actin cables in actin-patch movement in Schizosaccharomyces pombe. Nat Cell Biol 3:235-244. CrossRef Medline

Perrais D, Kleppe IC, Taraska JW, Almers W (2004) Recapture after exocytosis causes differential retention of protein in granules of bovine chromaffin cells. J Physiol 15:413-428. Medline

Reichl EM, Ren Y, Morphew MK, Delannoy M, Effler JC, Girard KD, Divi S, Iglesias PA, Kuo SC, Robinson DN (2008) Interactions between myosin and actin crosslinkers control cytokinesis contractility dynamics and mechanics. Curr Biol 18:471-480. CrossRef Medline

Richards DA, Guatimosim C, Betz WJ (2000) Two endocytic recycling routes selectively fill two vesicle pools in frog motor nerve terminals. Neuron 27:551-559. CrossRef Medline

Richards DA, Rizzoli SO, Betz WJ (2004) Effects of wortmannin and latrunculin A on slow endocytosis at the frog neuromuscular junction. J Physiol 557:77-91. CrossRef Medline

Riedl J, Crevenna AH, Kessenbrock K, Yu JH, Neukirchen D, Bista M, Bradke F, Jenne D, Holak TA, Werb Z, Sixt M, Wedlich-Soldner R (2008) Lifeact: a versatile marker to visualize F-actin. Nat Methods 5:605-607. CrossRef Medline

Rohatgi R, Ma L, Miki H, Lopez M, Kirchhausen T, Takenawa T, Kirschner MW (1999) The interaction between N-WASP and the Arp2/3 complex links Cdc42-dependent signals to actin assembly. Cell 97:221-231. CrossRef Medline

Saarikangas J, Zhao H, Lappalainen P (2010) Regulation of the actin cytoskeleton-plasma membrane interplay by phosphoinositides. Physiol Rev 90:259-289. CrossRef Medline

Shupliakov O, Bloom O, Gustafsson JS, Kjaerulff O, Low P, Tomilin N, Pieribone VA, Greengard P, Brodin L (2002) Impaired recycling of synaptic vesicles after acute perturbation of the presynaptic actin cytoskeleton. Proc Natl Acad Sci USA 99:14476-14481. CrossRef Medline

Torregrosa-Hetland CJ, Villanueva J, Giner D, Lopez-Font I, Nadal A, Quesada I, Viniegra S, Expósito-Romero G, Gil A, Gonzalez-Velez V, Segura J, Gutiérrez LM (2011) The F-actin cortical network is a major factor influencing the organization of the secretory machinery in chromaffin cells. J Cell Sci 1:727-734. CrossRef Medline

Trifaró JM, Gasman S, Gutierrez LM (2008) Cytoskeletal control of vesicle transport and exocytosis in chromaffin cells. Acta Physiol (Oxf) 192:165172. CrossRef Medline

Uehara R, Goshima G, Mabuchi I, Vale RD, Spudich JA, Griffis ER (2010) Determinants of myosin II cortical localization during cytokinesis. Curr Biol 20:1080-1085. CrossRef Medline

Várnai P, Lin X, Lee SB, Tuymetova G, Bondeva T, Spät A, Rhee SG, Hajnóczky G, Balla T (2002) Inositol lipid binding and membrane localization of isolated pleckstrin homology (PH) domains. Studies on the $\mathrm{PH}$ domains of phospholipase C delta 1 and p130. J Biol Chem 277:2741227422. CrossRef Medline

Wen PJ, Osborne SL, Zanin M, Low PC, Wang HT, Schoenwaelder SM, Jackson SP, Wedlich-Soldner R, Vanhaesebroeck B, Keating DJ, Meunier FA (2011) Phosphatidylinositol(4,5)bisphosphate coordinates actinmediated mobilization and translocation of secretory vesicles to the plasma membrane of chromaffin cells. Nat Commun 2:491. CrossRef Medline

Wu W, Wu LG (2007) Rapid bulk endocytosis and its kinetics of fission pore closure at a central synapse. Proc Natl Acad Sci USA 104:10234-10239. CrossRef Medline

Yumura S, Ueda M, Sako Y, Kitanishi-Yumura T, Yanagida T (2008) Multiple mechanisms for accumulation of myosin II filaments at the equator during cytokinesis. Traffic 9:2089-2099. CrossRef Medline 